\title{
Dihydrotachysterol intoxication treated with pamidronate: a case report
}

Mojca Jensterle, Marija Pfeifer, Matjaz Sever and Tomaz Kocjan*

\begin{abstract}
Introduction: Hypoparathyroidism is a chronic condition which requires a lifelong substitution with vitamin D analogues and careful monitoring. This is especially true for older patients and older compounds as dihydrotachysterol with longer half-life that might lead to long-lasting hypercalcemic episodes.

Case presentation: A 74-year old male patient with postsurgical hypoparathyroidism who has been successfully supplemented with dihydrotachysterol $(1.7 \mathrm{ml} /$ day) for over 50 years presented with neuropsychiatric disturbances, constipation, renal insufficiency and polyuria. Laboratory investigation demonstrated serum calcium $3.7 \mathrm{mmol} / \mathrm{L}$, serum creatinine $180 \mathrm{micromol} / \mathrm{L}$, urine calcium excretion $1.1 \mathrm{mmol} / \mathrm{mmol}$ of the creatinine, normal $25 \mathrm{OH}_{\text {vitamin }} \mathrm{D}_{3}$ and low parathormone and 1,25 di OH vitamin $\mathrm{D}_{3}$. Careful history revealed that he has been erroneously taking $2.5 \mathrm{ml}$ of dihydrotachysterol per day for at least 6 to 8 weeks that caused vitamin D intoxication and symptomatic hypercalcemia. He was treated with intravenous saline infusion, prednisolone and $60 \mathrm{mg}$ of intravenous sodium pamidronate. On the fourth day after admission serum calcium dropped rapidly within the reference range. The treatment for hypoparathyroidism had to be reinstituted 10 days after dihydrotachysterol had been discontinued when the patient was switched to shorter acting calcitriol.

Conclusions: Here we reported that the immediate use of pamidronate in addition to classic treatment of dihydrotachysterol intoxication with intravenous saline, diuretics and glucocorticoids is an effective treatment choice that leads to rapid resolution of hypercalcemia.
\end{abstract}

\section{Background}

Vitamin D intoxication is a rare cause of hypercalcemia. However, it should be considered even after uneventful chronic therapy of hypoparathyroidism, especially in older patients. Common treatment regimens for hypoparathyroidism include colecalciferol (vitamin $\mathrm{D}_{3}$ ) or ergocalciferol (vitamin $\mathrm{D}_{2}$, alfacalcidol (1 alpha-hydroxycolecalciferol) and calcitriol. Colecalciferol and ergocalciferol are the least expensive preparations but have the longest duration of action. This is due to the storage of these compounds in body fat and consequent slow release which may result in prolonged toxicity. The newer preparations, alfacalcidol and calcitriol, which do not require renal 1 alpha hydroxylation, are much more potent, have the advantage of shorter half-life and thereby minimal risk of prolonged toxicity. Calcitriol is the natural active metabolite and, unlike alfa-

* Correspondence: tomaz.kocjan@kclj.si

1 Department of Endocrinology, Diabetes and Metabolic Diseases, University Medical Centre, Zaloska 7, SI-1000 Ljubljana, Slovenia

Full list of author information is available at the end of the article calcidol, does not require the hepatic 25-hydroxylation [1]. Nowadays, it is the drug of choice for treating hypoparathyroidism.

Dihydrotachysterol is only seldom used in the treatment of hypoparathyroidism. It is a half synthetic analog of vitamin D and is converted to the active form in the body. Dihydrotachysterol actions and pharmacokinetics resemble those of vitamin $\mathrm{D}_{3}$ including the prolonged toxicity. It stimulates calcium and phosphate absorption from the small intestine, promotes mobilization of calcium from bone to blood and promotes renal tubular reabsorption of phosphate. It is stored in liver, fat, skin, muscle, and bone and excreted in feces. Its peak effect on serum calcium concentration is reached in 2-4 weeks and lasts for about 9 weeks which means a prolonged toxicity. It is of note, that dihydrotachysterol is not detected by the $25 \mathrm{OH} \mathrm{D}_{3}$ and $1,25 \mathrm{di}$ $\mathrm{OH}$ vitamin $\mathrm{D}_{3}$ assays [2].

Vitamin D intoxication is a treatable cause of hypercalcemia. Calcitriol-induced hypercalcemia usually lasts only 
one to two days due to the short biologic half-life of the compound. Discontinuing the calcitriol, increasing salt and fluid intake or additional hydration with intravenous saline may be the only treatment needed. In contrast, hypercalcemia induced by intoxication with longer lasting preparations such as dihydrotachysterol, vitamin $\mathrm{D}_{3}$ and vitamin $\mathrm{D}_{2}$ takes longer to resolve because of deposition of ingested vitamin $\mathrm{D}$ in fat and its consequent slow release. Therefore, more aggressive therapy including intravenous hydration, diuretics and glucocorticoids is needed.

However, it has been demonstrated that the major cause of hypercalcemia due to vitamin D intoxication is actually the increased bone resorption [3]. If this is the case, specific inhibitors of bone resorption as bisphosphonates might provide more effective treatment than conventional therapy. We carried out a systematic review of most previously published case reports using bisphosphonate treatment in patients with vitamin D intoxication. The results are presented in Table 1[4-15]. We also found three review articles that are reported in the following paragraph.

Selby et al. [3] observed a rapid reduction in plasma calcium concentration with pamidronate in a group of patients with vitamin D intoxication. In the same group corticosteroids had a more delayed effect. They concluded that hypercalcemia of vitamin D intoxication is mediated by increased bone resorption and bisphosphonates should have a role in its management. Rizzoli et al. [16] reported that intravenous administration of clodronate corrected hypercalcemia and hypercalciuria of vitamin D intoxication whereas prednisolone therapy barely affected biochemical values. Finally, Quack et al. [17] reported successful application of single dose pamidronate $15 \mathrm{mg}$ even in four patients with dihydrotacysterol intoxication regardless of their renal failure.

To our knowledge, the combination of conventional treatment and pamidronate, has never been introduced simultaneously and immediately after admittance in a patient with dihydrotachysterol intoxication. Considering the extremely brisk response in our patient we believe that this is an effective and advantageous treatment regimen which also enables rapid reinstitution of the substitution therapy.

\section{Case presentation}

A 74-year old male patient was sent to the emergency neurologic outpatient clinic because of progressive confusion, lethargy, dysarthria, fatigue and weakness in the last week. He complained of constipation, anorexia and vague abdominal pain. The CT scan of the brain that was immediately performed by the neurologist was normal.

An interview with his son who arrived a few hours later revealed that the patient had been treated for hypertension and postsurgical hypoparathyroidism without any other important comorbidity. He was followed regularly at an endocrinology outpatient clinic once yearly. His last visit two months before current admission showed normal labo- ratory values including serum calcium, creatinine and phosphate. He had near-total thyroidectomy for benign goiter back in 1955. Following the surgery he had episodes of tetany and postsurgical hypoparathyroidism was diagnosed 2 years later. A therapy with dihydrotachysterol was introduced in 1957. In 1972 he had a single episode of renal colic which ended with spontaneous stone passage. In 1995 thiazide diuretic was added to the dihydrotachysterol due to hypercalciuria. There were several attempts to introduce shorter acting vitamin $\mathrm{D}$ derivatives during 50 years of the disease history, but finally the patient had always rejected all new medications and switched back to dihydrotachysterol.

On examination, he was lethargic, dysarthric with slow tongue movements and poor cognitive estimates, hypertensive (blood pressure was 165/95 $\mathrm{mmHg}$ ), dehydrated. Cardiovascular, respiratory and abdominal examinations were unremarkable. Cranial nerve examination was normal. He had bradykinesia with decreased power of the limbs, in association with decreased reflexes and slightly increased tone in the axial parts of the limbs. Plantar responses were normal. After admission we noted also severe constipation and polyuria few days later.

When laboratory investigations demonstrated serum calcium of $3.7 \mathrm{mmol} / \mathrm{L}$, serum creatinine $188 \mu \mathrm{mol} / \mathrm{L}$ and urea $16.2 \mathrm{mmol} / \mathrm{L}$, he was admitted to the endocrinology department where some additional tests were done. Urinary calcium excretion in the 24 hours collection was increased to $1.1 \mathrm{mmol} / \mathrm{mmol}$ of creatinine. Alkaline phosphatase, phosphate, $25 \mathrm{OH}$ vitamin $\mathrm{D}_{3}$, ACE (angiotensin converting enzyme), PSA and CEA were normal. Serum parathormone and 1,25 di $\mathrm{OH}$ vitamin $\mathrm{D}_{3}$ were low (Table 2). The QTc interval on ECG was within reference range. Test of occult blood in stool specimen was negative. Abdominal ultrasound showed normally sized kidneys, no renal calculi and no nephrocalcinosis. Chest X-ray was normal.

Based on the history the patient was diagnosed with vitamin D intoxication due to dihydrotachysterol overdose. Differential diagnosis included malignancy and sarcoidosis. However, according to the data collected they seemed unlikely and therapy was initiated before their proper exclusion. The patient was treated according to conventional treatment regimen for this condition with intravenous saline infusion, careful administration of loop diuretic (furosemide) and methylprednisolone. We additionally applied $60 \mathrm{mg}$ of pamidronate sodium in slow intravenous infusion over 4 hours. Two days after the admission the patient became less confused. His communication improved and he admitted that he had been mistakenly taking 75 drops $(2.5$ $\mathrm{ml}$ ) of dihydrotachysterol per day for the last 6 to 8 weeks instead of his usual daily dose of 50 drops $(1.7 \mathrm{ml})$. The reason for this sudden change of his regimen remained a mystery. On the fourth day after admission serum calcium dropped rapidly to the reference range. The observed con- 
Table 1: Systematic review of previously published case reports using bisphosphonate treatment in patients with vitamin $D$ intoxication.

\begin{tabular}{|c|c|c|c|c|c|c|c|c|c|c|}
\hline Ref. & Age, Sex & Underlying disease & $\begin{array}{l}\text { Vitamin D } \\
\text { compound }\end{array}$ & $\begin{array}{l}\text { Serum Ca/ } \\
P(\mathrm{mg} / \mathrm{dl})\end{array}$ & $\begin{array}{l}\text { Creatinine } \\
\text { (mg/dl) }\end{array}$ & $\begin{array}{l}\text { PTH } \\
(\mathrm{pg} / \\
\mathrm{ml})\end{array}$ & $\begin{array}{l}\text { 25OHD3 } \\
\text { (ng/ml) }\end{array}$ & Treatment & $\begin{array}{l}\text { Other } \\
\text { treatment }\end{array}$ & $\begin{array}{l}\text { Response } \\
\text { time }\end{array}$ \\
\hline 4. & 40 years, $M$ & Hypoparathyroidism & $\begin{array}{l}\text { Ergocalcife } \\
\text { rol } 100.000 \\
\text { U/day for } 3 \\
\text { years }\end{array}$ & 13.0 & 4.2 & & 121 & $\begin{array}{l}\text { Disodium } \\
\text { etidronate } \\
400 \mathrm{mg}\end{array}$ & $\begin{array}{l}\text { Hydration, } \\
\text { prednisone }\end{array}$ & 42 weeks \\
\hline 5. & 7 months & None & Vitamin D & & & & & Alendronate & & \\
\hline 6. & 3 months, $M$ & None & $\begin{array}{l}\text { Vitamin D } \\
1.200 .000 \\
\text { U/day }\end{array}$ & $18.5 / 3.2$ & & $<1.0$ & 360 & $\begin{array}{l}\text { Alendronate } \\
5-10 \mathrm{mg} / \text { day }\end{array}$ & $\begin{array}{l}\text { Hydration, } \\
\text { diuretics }\end{array}$ & 18 days \\
\hline 7. & 31 years, $F$ & Hypoparathyroidism & $\begin{array}{l}\text { Dyhydrota } \\
\text { hysterol } 4 \\
\mathrm{mg} / \text { day for } \\
6 \text { months }\end{array}$ & $4.1 \mathrm{mmol}$ & 5.5 & & & $\begin{array}{l}\text { Pamidronate } \\
20 \mathrm{mg} \text { once }\end{array}$ & $\begin{array}{l}\text { Hydration, } \\
\text { diuretics }\end{array}$ & 20 weeks \\
\hline 8. & 16 months, $M$ & None & Vitamin D & 18 & & & & Pamidronate & $\begin{array}{l}\text { Hydration, } \\
\text { furosemide } \\
\text { ' glucocortio } \\
\text { ids }\end{array}$ & \\
\hline 9. & 8 months, $\mathrm{F}$ & Vitamin D deficiency & $\begin{array}{l}25 \text {-hydroxy } \\
\text { vitamin D } \\
1.200 .000 \mathrm{U}\end{array}$ & $14.2 / 4.8$ & & $<3$ & 210 & $\begin{array}{l}\text { Alendronate } \\
5 \mathrm{mg} / \text { day }\end{array}$ & $\begin{array}{l}\text { Hydration, } \\
\text { furosemide }\end{array}$ & 3 days \\
\hline 9. & 35 days, $M$ & Vitamin D deficiency & $\begin{array}{l}25 \text {-hydroxy } \\
\text { vitamin D } \\
600.000 \mathrm{U}\end{array}$ & $14.5 / 5.9$ & & $<3$ & 240 & $\begin{array}{l}\text { Alendronate } \\
5-10 \mathrm{mg} / \text { day }\end{array}$ & $\begin{array}{l}\text { Hydration, } \\
\text { furosemide }\end{array}$ & 8 days \\
\hline 10. & 3 months, $M$ & None & $\begin{array}{l}\text { Vitamin D } \\
2.560 .000 \mathrm{U}\end{array}$ & $16.4 / 6.7$ & & & 268 & $\begin{array}{l}\text { Pamidronate } \\
20 \mathrm{mg} \text { twice }\end{array}$ & $\begin{array}{l}\text { Hydration, } \\
\text { furosemide } \\
\text { ' } \\
\text { prednisolo } \\
\text { ne }\end{array}$ & 36 hours \\
\hline 11. & 6 months & None & Vitamin D & & & & & $\begin{array}{l}\text { Pamidronate } \\
1 \mathrm{mg} / \mathrm{kg} / \text { day } \\
\text { twice }\end{array}$ & $\begin{array}{l}\text { Hydration, } \\
\text { furosemide } \\
\text { ' } \\
\text { calcitonine, } \\
\text { prednisolo } \\
\text { ne }\end{array}$ & 2 days \\
\hline
\end{tabular}




\begin{tabular}{|c|c|c|c|c|c|c|c|c|c|c|}
\hline 12. & 11 months, $F$ & None & $\begin{array}{l}\text { Cholecalcif } \\
\text { erol > } \\
900.000 \mathrm{U}\end{array}$ & 18 & & 1.84 & 200 & $\begin{array}{l}\text { Alendronat } 5 \\
\mathrm{mg} / \text { day for } \\
21 \text { days }\end{array}$ & $\begin{array}{l}\text { Calcitonine } \\
\text { glucocortic } \\
\text { oid, oral } \\
\text { phosphate } \\
\text { s }\end{array}$ & 3 weeks \\
\hline 12. & 4 months, $F$ & $\begin{array}{l}\text { Misdiagnosed for } \\
\text { rickets }\end{array}$ & $\begin{array}{l}\text { Cholecalcif } \\
\text { erol } \\
600.000 \mathrm{U}\end{array}$ & 14.9 & & 4.1 & $>160$ & $\begin{array}{l}\text { Pamidronate } \\
, 1 \mathrm{mg} / \mathrm{kg} / \\
\text { day for } 9 \\
\text { days, } \\
\text { alendronate } \\
10 \mathrm{mg} / \text { day } \\
\text { for } 6 \text { weeks }\end{array}$ & $\begin{array}{l}\text { Hydration, } \\
\text { glucocrtico } \\
\text { ids, } \\
\text { calcitonin, } \\
\text { phosphate } \\
\text { s }\end{array}$ & 9 weeks \\
\hline 13. & 77 years, $F$ & Osteoporosis & $\begin{array}{l}\text { Vitamin D } \\
50.000 \mathrm{U} / \\
\text { day for } 6 \\
\text { days }\end{array}$ & 21 & 1.9 & & 280 & $\begin{array}{l}\text { Pamidronate } \\
90 \mathrm{mg} \text { once }\end{array}$ & Hydration & 24 hours \\
\hline 14. & 7 years, $M$ & Vitamin D deficiency & $\begin{array}{l}\text { Vitamin D } \\
300.000 \mathrm{U} / \\
\text { day for } 15 \\
\text { days }\end{array}$ & $12.1 / 3.4$ & & & $>400$ & $\begin{array}{l}\text { Alendronate } \\
5-10 \mathrm{mg}\end{array}$ & $\begin{array}{l}\text { Hydration, } \\
\text { diuretic }\end{array}$ & 16 days \\
\hline 15. & 76 years, $F$ & Hypoparathyroidism & $\begin{array}{l}\text { Ergocalcife } \\
\text { rol } 100.000 \\
\text { U/day, } 12 \\
\text { years }\end{array}$ & $15.3 / 3.0$ & & & & $\begin{array}{l}\text { Pamidronate } \\
45 \mathrm{mg} \text { five } \\
\text { times }\end{array}$ & $\begin{array}{l}\text { Hydration, } \\
\text { prednisolo } \\
\text { ne }\end{array}$ & 11 months \\
\hline
\end{tabular}


Table 2: Laboratory findings upon admission.

\begin{tabular}{lll}
\hline & Patient & Reference range \\
\hline S-calcium & 3.7 & $2.1-2.6 \mathrm{mmol} / \mathrm{L}$ \\
S-phosphate & 1.1 & $0.8-1.4 \mathrm{mmol} / \mathrm{L}$ \\
S-creatinine & 188 & $44-97 \mu \mathrm{mol} / \mathrm{L}$ \\
Urinary calcium excretion in the 24 hour & 1.1 & $0.13-0.45 \mathrm{mmoL} / \mathrm{mmoL} \mathrm{of} \mathrm{the} \mathrm{creatinine}$ \\
collection & 1.08 & \\
Alkaline phosphatase & $<3$ & $<1.5 \mu \mathrm{cat} / \mathrm{L}$ \\
Parathormone & 46 & $12-72 \mathrm{ng} / \mathrm{L}$ \\
25 OH D3 & 14 & $>75 \mathrm{nmol} / \mathrm{L}$ \\
1,25 di OH vitamin $\mathrm{D}_{3}$ & 1.36 & $40-155 \mathrm{pmol} / \mathrm{L}$ \\
PSA & 0.17 & $<3 \mu \mathrm{g} / \mathrm{L}$ \\
ACE & & $0.13-0.47 \mu \mathrm{cat} / \mathrm{L}$ \\
\hline
\end{tabular}

stipation and polyuria resolved in few days after normalization of serum calcium concentrations. The treatment for hypoparathyroidism had to be reinstituted 10 days after dihydrotachysterol had been discontinued. The patient was now easily switched to shorter acting vitamin $\mathrm{D}$ derivate calcitriol $(0.25 \mu \mathrm{g}$ twice per day) which maintained a normal serum and urinary calcium concentration without a thiazide. However, two weeks after the discharge from the department of endocrinology he discontinued calcitriol and again started taking dihydrotachysterol, since old habits die hard. Laboratory values and treatment during follow up are reported in Figure 1.

\section{Conclusion}

Most symptoms of hypercalcemia are non-specific and are difficult to be perceived by physicians. It should be realized that vitamin $\mathrm{D}$ in all its forms can be a demanding drug to use in a lifelong treatment of hypoparathyroidism. Continuous vigilance is required, especially in older people. In comparison to short acting vitamin D derivatives hypercalcemic episodes with dihydrotachysterol appear to last longer and may occur with higher incidence. Whenever possible, a switch to shorter acting vitamin $\mathrm{D}$ derivatives is recommended. The first line treatment of vitamin D intoxication includes intravenous hydration, diuretics and glucocorticoids. Since hypercalcemia of hypervitaminosis D is predominantly caused by increased bone resorption, bisphosphonates might provide more effective treatment. We reported that the instant use of pamidronate and methylprednisolone for moderate to severe hypercalcemia due to vitamin D intoxication with dihydrotachysterol is an effective treatment choice. Considering the prompt response we believe that bisphosphonates should be initiated in the early stages of treatment of vitamin D intoxication.

\section{Consent}

Written informed consent was obtained from the patient for publication of this case report and accompanying tables. A copy of the written consent is available for review by the Editor-in-Chief of this journal.

Competing interests

The authors declare that they have no competing interests.

\section{Authors' contributions}

MJ was a major contributor in writing the manuscript. MP has been involved in revising the manuscript critically for important intellectual content. MS contributed in writing the manuscript. TK has made substantial contributions to conception and design of the treatment regimen. All authors read and approved the final manuscript.

\section{Author Details}

Department of Endocrinology, Diabetes and Metabolic Diseases, University Medical Centre, Zaloska 7, SI-1000 Ljubljana, Slovenia

Received: 10 July 2008 Accepted: 26 March 2010 Published: 26 March 2010

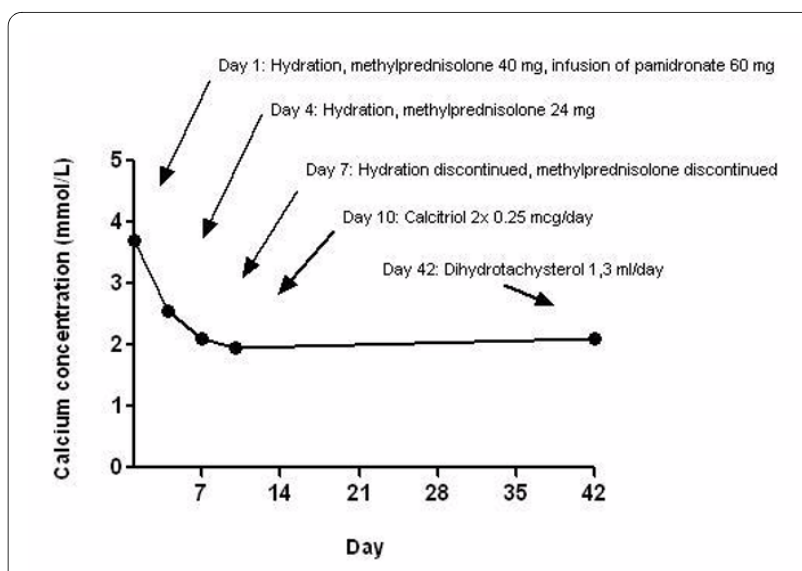

Figure $\mathbf{1}$ Laboratory findings and treatment follow up. Reference range for serum calcium is $2.1-2.6 \mathrm{mmol} / \mathrm{L}$. 


\section{References}

1. O'Riordan JLH: Treatment of Hypoparathyroidism. In The Parathyroids Edited by: Bilezikian JP, Levine MA, Marcus J. Raven Press; 1994:801-804.

2. Schwartzman MS: Vitamin D toxicity complicating the treatment of senile, postmenopausal and glucocorticoid-induced osteoporosis. Am J Med 1987, 82:224-230

3. Selby PL, Davies M, Marks JS, Mawer EB: Vitamin D intoxication causes hypercalcaemia by increased bone resorption which responds topamidronate. Clin Endocrinol 1995, 43:531-536.

4. Allen SH, Shah JH: Calcinosis and metastatic calcification due to vitamin Dintoxication. A case report and review. Horm Res 1992, 37(1-2):68-77.

5. Atabek ME, Pirgon O, Sert A: Oral alendronate therapy for severe vitamin D intoxication of the infant with nephrocalcinosis. J Pediatr Endocrinol Metab 2006, 19(2):169-72.

6. Bereket $A$, Erdogan T: Oral bisphosphonate therapy for vitamin $D$ intoxication of the infant. Pediatrics 2003, 111(4Pt 1):899-901.

7. Blind E, Fassnacht M, Körber C, Körber-Hafner N, Reiners C, Allolio B: Severe Vitamin $D$ (dihydrotachysterol)-intoxication with temporary anemia and hypercalcemia responsive to bisphosphonates. Dtsch Med Wochenschr 2001, 126(12):T21-T24.

8. Chatterjee M, Speiser PW: Pamidronate treatment of hypercalcemia caused by vitamin D toxicity. J Pediatr Endocrinol Metab 2007. 20(11):1241-8

9. Doneray H, Ozkan B, Caner I, Ozkan A, Karakelleoglu C: Intragastric alendronate therapy in two infants with vitamin $D$ intoxication: a new method. Clin Toxicol (Phila) 2008, 46(4):300-2.

10. Ezgü FS, Atalay $Y$, Gücüyener $K$, Tunç $S$, Koç E, Ergenekon E, Tiraş U: Neuron-specific enolase levels and neuroimaging in asphyxiated term newborns. J Child Neurol 2002, 17(11):824-9.

11. Gurkan F, Davutoglu M, Bosnak M, Ece A, Dikici B, Bilici M, Haspolat K: Pamidronate treatment in acute vitamin D intoxication. J Endocrinol Invest 2004, 27(7):680-2.

12. Hatun S, Cizmecio@lu F: Use of alendronate in the treatment of vitamin D intoxication in infants. Turk J Pediatr 2005, 47(4):373-5.

13. Lee DC, Lee GY: The use of pamidronate for hypercalcemia secondary to acute vitamin D intoxication. J Toxicol Clin Toxicol 1998, 36(7):719-21

14. Orbak Z, Doneray H, Keskin F, Turgut A, Alp H, Karakelleoglu C: Vitamin D intoxication and therapy with alendronate (case report and review of literature). Eur J Pediatr 2006, 165(8):583-4.

15. Sato K, Emoto N, Toraya S, Tsushima T, Demura H, Tsuji N, Inaba S, Takeuchi A, Kobayashi T: Progressively increased serum 1,25-dihydroxyvitamin D2 concentration in a hypoparathyroid patient with protracted hypercalcemia due to vitamin D2 intoxication. Endocr J 1994, 41(4):329-37.

16. Rizzoli R, Stoermann C, Ammann P, Bonjour JP: Hypercalcemia and hyperosteolysis in vitamin D intoxication: effects of clodronatetherapy. Bone 1994, 15:193-198.

17. Quack I, Zwernemann C, Weiner SM, Sellin L, Henning BF, Waldherr R, et al: Dihydrotachysterol therapy for hypoparathyroidism: consequences of inadequate monitoring. Five cases and a review. Exp Clin Endocrinol Diabetes 2005, 113:376-380.

doi: 10.1186/1757-1626-3-78

Cite this article as: Jensterle et al., Dihydrotachysterol intoxication treated with pamidronate: a case report Cases Journal 2010, 3:78

\section{Submit your next manuscript to BioMed Central} and take full advantage of:

- Convenient online submission

- Thorough peer review

- No space constraints or color figure charges

- Immediate publication on acceptance

- Inclusion in PubMed, CAS, Scopus and Google Scholar

- Research which is freely available for redistribution

Submit your manuscript at www.biomedcentral.com/submit
C Biomed Central 